\title{
Arsenic translocation in rice cultivation and its implication for human health
}

José M. Bastīas ${ }^{{ }^{*}}$, and Tatiana Beldarrain ${ }^{1}$

\section{ABSTRACT}

Arsenic (As) is a toxic metalloid for plants and animals. Large amounts of As have been released in arable soils through anthropogenic activities, use of contaminated irrigation water, and mining among others. Rice (Oryza sativa $\mathrm{L}$.) is one of the most consumed cereals worldwide; it is an important route of exposure for As. The objective of this review was to explain possible mechanisms involved in As absorption that contaminate rice plant through the soil and water, and to mention studies that have been conducted to minimize the risk of human exposure. The root is able to absorb and accumulate large amounts of As, but only small amounts are translocated to the grain and tillers. Arsenic concentrations in rice tissues decrease from the root to the grain. Information about As translocation in rice is sparse and research is directed toward studying the molecular mechanism of absorption and accumulation in the grain because it has not yet been explained. Some rice varieties have been developed that are resistant to high soil As concentrations and are not able to translocate the metalloid toward the root. Many studies suggest that not all ingested inorganic As accumulated in the gastrointestinal tract is absorbed into the bloodstream and produces toxicity. It is therefore recommended that As bioavailability be evaluated in imported or domestic Chilean rice to more precisely estimate human health risk.

Key words: Inorganic arsenic, Oryza sativa, total arsenic, translocation.

\section{INTRODUCTION}

Rice (Oryza sativa L.) is one of the main foods in many countries, and this explains why annual production is high. The United States Department of Agriculture (USDA) reported that production in 2014 was 474.86 million tons (ODEPA, 2014), and the major producers were China, India, Indonesia, Bangladesh, and Vietnam. Some of these countries report soil and groundwater contamination with high arsenic (As) levels (Rahman et al., 2014a). Rice is characterized as an efficient As accumulator because of the combination of biogeochemical characteristics of agricultural soils and its ability to absorb and transport As (Kumar et al., 2015). The International Agency for Research on Cancer has classified inorganic arsenic (iAs) as arsenite $\left(\mathrm{As}^{\mathrm{III}}\right)$ and arsenate $\left(\mathrm{As}^{\mathrm{V}}\right)$ as type 1 carcinogenic agents (IARC, 2012); hence, its importance for public health. Therefore, how to decrease As exposure in rice is an important concern for the scientific community (Rahman et al., 2014a). This review explains possible mechanisms involved in As absorption that contaminate the rice plant through the soil and water, and mentions studies that have been conducted to minimize the risk for human exposure.

\section{Arsenic in rice cultivation}

It is estimated that more than 150 million people worldwide have been affected by increased As concentrations. Oral ingestion is the major human route of exposure (Welna et al., 2015). Arsenic contamination has been reported in many places in the world, such as Bangladesh, India, China, Turkey, Argentina, Chile, and Colombia (Bundschuh et al., 2012; Gan et al., 2014; Tong et al., 2014). This element is widely distributed in nature, and its accumulation in soils is caused by the use of pesticides, fertilizers, and the burning of fossil fuels; its level in soils depends on the anthropogenic activity, the distance from the source of contamination, as well as contaminant dispersion (Bastías et al., 2013a; 2013b).

\section{Toxicity of arsenic species and their occurrence in rice cultivation}

Arsenic toxicity is based on species (Jomova et al., 2011). The rice grain contains both organic and inorganic As (iAs). Arsenite $\left(\mathrm{As}{ }^{\mathrm{III}}\right)$ and dimethylarsenic acid (DMA) are the typical species. Furthermore, it can contain arsenate $\left(\mathrm{As}^{\mathrm{V}}\right)$, monomethylarsenic acid (MMA), and occasionally tetramethylarsonate. Other authors 
include monomethylarsenic acid (MMA), arsenobetaine (AsB), and arsenocholine (AsC) (Meharg and Zhao, 2012).

Inorganic $\mathrm{As}$ is mainly found as $\mathrm{As}^{\mathrm{V}}$ in aerobic environments and water, while $\mathrm{As}^{\mathrm{III}}$ prevails in anoxic and neutral environments. However, they can interconvert when there are changes in the redox potential, $\mathrm{pH}$, and the occurrence of microorganisms (Zhao et al., 2010; Nearing et al., 2014). The bacteria that reduce $\left(\mathrm{As}^{\mathrm{V}}\right)$ and oxidize $\mathrm{As}^{\mathrm{III}}$ are found in the soil. Arsenate reduction by microorganisms occurs through two mechanisms: $\mathrm{As}^{\mathrm{V}}$ reduction serves as a terminal electron acceptor during anaerobic respiration and detoxification in which $\mathrm{As}^{\mathrm{V}}$ is reduced into $\mathrm{As}{ }^{\mathrm{III}}$ and pumped out of the microbial cells (Zhao et al., 2010).

It has been observed that $\mathrm{As}{ }^{\mathrm{III}}$ is 10 times more toxic than As ${ }^{\mathrm{V}}$; monomethylarsonite (MMA ${ }^{\mathrm{III}}$ ) and dimethylarsonite (DMA ${ }^{\mathrm{III}}$ ) are more toxic than $\mathrm{As}^{\mathrm{V}}$ and $\mathrm{As}^{\mathrm{III}}$. In turn, these are more toxic than monomethylarsonate $\left(\mathrm{MMA}^{\mathrm{V}}\right)$ and dimethylarsenate $\left(\mathrm{DMA}^{\mathrm{V}}\right)$. The least toxic is trimethylarsenic oxide (TMAO) (Rahman and Hassler, 2014).

Biomethylation of iAs species has been considered as a potential detoxification mechanism of microorganisms; this results in the production of trivalent methylarsenic species $\left(\mathrm{MMA}^{\mathrm{III}}\right.$ and $\mathrm{DMA}^{\mathrm{III}}$ ) as shown in Figure 1. Both MMA ${ }^{\mathrm{III}}$ and $\mathrm{DMA}^{\mathrm{III}}$ are intermediaries in the biosynthetic route of pentavalent methylarsenic species $\left(\mathrm{MMA}^{\mathrm{V}}\right.$ and $\left.\mathrm{DMA}^{\mathrm{V}}\right)$, and they are the most toxic forms of As (Dopp et al., 2010). Trivalent intermediaries are structurally different from their pentavalent counterparts; they are more reactive and less carcinogenic (Rahman and Hassler, 2014). It has been found

Figure 1. Possible routes of arsenic methylation by microorganisms and its excretion outside the phytoplankton microbial cell.

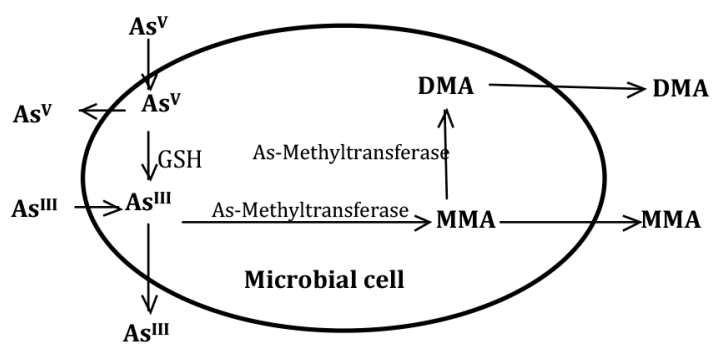

As ${ }^{\mathrm{V}}$ : Arsenate, As ${ }^{\mathrm{III}}$ : arsenite, GSH: glutathione, MMA: mono methylarsonate, DMA: dimethylarsenate.

Table 1. Elements in the soil that interact with arsenic. that $\mathrm{As}^{\mathrm{III}}$ and MMA ${ }^{\mathrm{III}}$ act through the same mechanism to produce toxicity, and $\mathrm{MMA}^{\mathrm{III}}$ creates a more stable binary complex in the active site of the enzyme than As ${ }^{\mathrm{III}}$ (Rahman and Hassler, 2014).

\section{Arsenic translocation in rice}

To reduce the ingestion of As, it is essential to know and identify the mechanisms involved in the accumulation and detoxification of rice. Its molecular mechanisms of intake, metabolism, and translocation have been identified in recent years. The chemistry of As in the rhizosphere is complex and controlled by several factors. There are four important elements that take part in As intake in rice: $\mathrm{Fe}, \mathrm{P}, \mathrm{S}$, and $\mathrm{Si}$ (Table 1) (Zhao et al., 2010).

Iron $(\mathrm{Fe})$ plays an important role in the biogeochemical cycle of As. Iron oxyhydroxides in the soil and/or on the plant root surface function as a strong As adsorbent. The reductive dissolution of $\mathrm{Fe}$ oxyhydroxides in a reducing environment releases As that is adsorbed by the rice plant, which leads to greater bioavailability of the metalloid. Oxygen is transported in the roots through root aerenchyma where it is consumed by the adjacent tissue cells or diffused toward the root apex or the rhizosphere. Oxygen transfer from the aerenchyma to the rhizosphere is called radial oxygen loss (ROL). It can oxidize elements in the rhizosphere soil, for example, $\mathrm{Fe}^{2+}$ to $\mathrm{Fe}^{3+}$, and cause the precipitation of toxic metals in the rhizosphere soil and on the root surface (Pan et al., 2014). Mobility of the metal is then altered in the rhizosphere. Aerenchymae develop in the rice plants to transfer $\mathrm{O}_{2}$ from the aerial parts of the plant to the roots, which results in the oxidation of ferrous iron into ferric iron and the precipitation of Fe oxides or hydroxides on the root surface (Pan et al., 2014). The Fe coating can sequester metals in wetland plant roots and modify As translocation from the roots to the shoots (Rahman et al., 2014c). Rhizosphere interactions therefore play a key role in controlling As bioavailability in rice cultivation (Deng et al., 2010).

Chemical reactions could occur in reducing environments under anoxic conditions that dissolve Fe minerals to which As is bound (Michael, 2013). The correlation between available soil $\mathrm{Fe}$ and $\mathrm{pH}$ is negative and highly significant, while the correlation is weak between available soil $\mathrm{Fe}$ and As found in the rice grain. One of the main Fe sources is the Fe-Mn-As

\begin{tabular}{|c|c|c|}
\hline Elements in soil & Importance & Reference \\
\hline Iron & $\begin{array}{l}\text { Fe serves as a strong adsorbent for As. } \\
\text { Reductive dissolution of Fe oxyhydroxides under a reducing environment releases adsorbed As, leading to } \\
\text { enhanced As availability to plants. } \\
\text { Fe-reducing bacteria are linked to As mobilization. }\end{array}$ & $\begin{array}{l}\text { Zhao et al., 2010; Pan } \\
\text { et al., } 2014\end{array}$ \\
\hline Phosphorus & Arsenate enters plant cells via phosphate transporters and also interferes with phosphate metabolism. & Rahman et al., 2014b \\
\hline Sulfur & $\begin{array}{l}\mathrm{S} \text { helps to detoxify As through the complexation of arsenite with thiol-rich peptides; these compounds can also } \\
\text { help to maintain As in the roots and restrict its translocation to the tillers. } \\
\text { It is particularly important to use adequate amounts of } \mathrm{S} \text { in soil fertilization in As-contaminated environments. }\end{array}$ & $\begin{array}{l}\text { Rai et al., 2011; } \\
\text { Rahman and Hassler, } \\
2014\end{array}$ \\
\hline Silicon & $\begin{array}{l}\text { Si fertilization can be an effective strategy to decrease As accumulation in rice grown in As-contaminated soil } \\
\text { because it increases the levels of antioxidant enzymes, isozymes, cysteine, GSH, and NPSH; it also reduces As- } \\
\text { induced lipid peroxidation in rice. }\end{array}$ & Tripathi et al., 2013 \\
\hline
\end{tabular}


fraction. The weak correlation between available Fe and iAs in the rice grain could be due to the $\mathrm{Fe}-\mathrm{Mn}$-As fractions or $\mathrm{pH}$ that influence available Fe (Jiang et al., 2014).

Another element is phosphorus (P). Because it is an analogue of $\mathrm{As}^{\mathrm{V}}$ phosphate $(\mathrm{Pi})$, this element could enter the cells through Pi transporters, which can interfere with the metabolism of the latter. Phosphate competes with $\mathrm{As}^{\mathrm{V}}$ and also with root adsorption of oxides and Fe hydroxides. When $P$ concentration increases, As uptake decreases. Some studies with different types of soil at different $\mathrm{P}$ and $\mathrm{Fe}$ concentrations found that there is a positive correlation between available Fe and iAs concentrations in the grain, while the correlation is negative when soil has available P (Jiang et al., 2014). It is also assumed that As mobility in organic acid-rich soils is reduced because the acid acts as a binding agent and/or in the formation of insoluble compounds that do not allow As to be absorbed by the roots (Jiang et al., 2014). Arsenate can be incorporated in the ATP (adenosine triphosphate) by replacing phosphates in the binding sites. This substitution, along with the inhibition of oxidative phosphorylation and interference in the correct ATP synthesis, increases $\mathrm{As}^{\mathrm{V}}$ toxicity (Rahman et al., 2014b).

In the case of sulfur $(\mathrm{S})$, this helps to detoxify As through the binding of As ${ }^{I I I}$ with thiol-rich peptides. This formation of compounds can also help to maintain As in the roots and restrict its translocation to the tillers. Arsenite is similar to sulfhydryl groups existing in cysteine residues that have a detrimental effect on the general metabolism of proteins, which increases its toxicity (Rai et al., 2011). Arsenite inhibits pyruvate dehydrogenase by binding to dihydrolipoamide sulfhydryl groups by decreasing the conversion of pyruvate into acetyl-coenzyme A (CoA) en el original tenia una referencia aqui (Bergquist et al., 2009). It also inhibits gluthatione production that protects cells against oxidative damage and phytochelatin (PC) production (of which gluthatione is a crucial component) as a result of which phytoplankton and plants lose the ability to detoxify numerous heavy metals (Rahman and Hassler, 2014). Maintaining enough S in soil fertilization can be particularly important in environments contaminated with As.

The role of silicon (LSil) transporters in As uptake is particularly important because similarities already exist between silicic acid and arsenious acid; this allows arsenious acid to penetrate into the root by the silicic acid transporter. The presence of Si decreases As phytotoxicity and increases the levels of antioxidant enzymes and their isozymes. It also enhances the concentrations of cysteine, GSH, and NPSH, and reduces As-induced lipid peroxidation in rice, Silicon fertilization can also be an effective strategy to decrease As accumulation in rice grown in As-contaminated soil (Tripathi et al., 2013).

\section{Proposed mechanisms for arsenic translocation in rice plant}

Arsenic is able to translocate from the roots to the tiller in rice. Some studies, conducted with different types of rice, have shown that there are differences in As concentration in plant parts with a decrease from the root to the grain (Welna et al., 2015). The highest As concentrations were in the root $\left(248 \pm 65 \mathrm{mg} \mathrm{kg}^{-1}\right)$ and the lowest in the grain $(1.25 \pm 0.23$ $\mathrm{mg} \mathrm{kg}^{-1}$ ) (Abedin et al., 2002). Some research studies have suggested that there is low As accumulation in the rice grain although plants grow in contaminated environments with high concentrations of the metalloid. Under hydroponic conditions, As concentrations in roots was $107.5 \mathrm{mg} \mathrm{kg}^{-1}$, while they decreased between 0.15 and $0.42 \mathrm{mg} \mathrm{kg}^{-1}$ in the grain (Abedin et al., 2002).

Metal-accumulating plants can translocate this element rapidly and efficiently to the tillers via the xylem. This implies that the xylem is loaded with this metalloid, passes it on to the vacuoles, and this is due to the characteristics of the root cell tonoplast (Rascio and Navari-Izzo, 2011). The root absorbs As as $\mathrm{As}^{\mathrm{V}}$ and $\mathrm{As}{ }^{\mathrm{III}}$. Arsenate penetrates because it is highly similar to the Pi transporters that belong to the PHT1 family (Ali et al., 2009). The plasma membrane of the root cells also has a higher density of $\mathrm{Pi} / \mathrm{As}^{\mathrm{V}}$ transporters than other plants that are not As accumulators because of constitutive gene overexpression (Rascio and Navari-Izzo, 2011). Arsenite is absorbed through the aquaglycoprotein NIPs (nodulin-like intrinsic proteins) (Meharg and Jardine, 2003) and by LSi1 transporters (Rascio and Navari-Izzo, 2011). The methylated forms of As, DMA, and MMA are absorbed through the aquaporins and use the same glycerol mechanism (Rahman et al., 2011).

Arsenate in the root cells is reduced by As reductase (AR) to $A s^{I I I}$ and leads to the conversion of glutathione (GSH) in its oxidized form (GSSG). Arsenite is transformed into trimethylarsenic oxide $\left(\mathrm{TMAO}^{\mathrm{V}}\right)$ and trimethylarsine oxide $\left(\mathrm{TMAO}^{\mathrm{III}}\right)$. The final product of the methylation route and the As volatile species are released into the environment. Another As detoxification route occurs by PC synthesis because of the condensation of three amino acids: cysteine, glutamate (Glu), and glycine (Gly). Finally, the sequestration of the As ${ }^{\mathrm{III}}$-PC compound occurs within the vacuole through the activity of the ABC transporters (Rahman and Hassler, 2014). Although $\mathrm{As}^{\mathrm{III}}$ is more toxic than $\mathrm{As}^{\mathrm{V}}$, it can bind to proteins or peptides that contain thiol groups, such as glutathione, phytochelatins, and metallothioneins, and form an inactive compound (Tsai et al., 2009) that protects the cell components of this toxin (Ali et al., 2009). The $\mathrm{As}^{\mathrm{III}}$ compounds are sequestered by the vacuole, but this mechanism is still unknown (Kumar et al., 2015). The main As compounds are $\mathrm{As}^{\mathrm{V}}$ and $\mathrm{As}{ }^{\mathrm{III}}$ that are found in the xylem sap of rice. Certain studies report that $\mathrm{As}^{\mathrm{III}}$ predominates in $80 \%$ of the analyzed sap samples in different rice species, including in those grown in $\mathrm{As}^{\mathrm{V}}$-rich soils; this suggests that reduction occurs in the root cells before passing to the xylem and the rest of the plant parts (Su et al., 2010). Other studies demonstrate the role played by the rice plasma membrane intrinsic proteins (OsPiP) in the permeability of $\mathrm{As}^{\mathrm{III}}$ (Mosa et al., 2012).

Of the total As (ToAs) absorbed by the root, only a very small part is sequestered in the leaf and grain vacuoles 
because the reduction and sequestration mechanisms are similar to those of the roots. The presence of different As species in the phloem is a prerequisite for it to be distributed to the rest of the plant (Yu et al., 2010). The possible As absorption mechanisms are shown in Figure 2.

\section{Factors influencing arsenic absorption in the rice plant}

There are studies that demonstrate a significant correlation between root porosity, tolerance, and As accumulation in rice (Wu et al., 2011). Other studies show that radial oxygen loss (ROL) rates were negatively correlated with As concentrations in rice roots among different genotypes. Rice genotypes with higher porosity can sequester less As of the $\mathrm{Fe}$ coating in the root, reduce its translocation to the plant, and finally to the grain (Deng et al., 2010).

Soil As accumulation over a long period of time increases its bioavailability for absorption by plant roots. Arsenic concentration is clearly dependent on rice variety (Rahman et al., 2014c), grain size and color (Meharg et al., 2008), procurement processes, and production environment (Zhao et al., 2010). Some studies report that As contamination in the rice grain is positively influenced by the amount of As in paddy irrigation water; however, no influence has been observed for As concentration in soils (Zavala and Duxbury, 2008).

The genotypes TD71 and Yinjingruanzhan contain less iAs and ToAs in their grains than genotypes IAPAR9 and Nanyangzhan. Genetic variation and As speciation are the two factors that influence plant As absorption (Wu et al., 2011; Pan et al., 2014). Regardless of genotype, all the studies show that iAs species predominate in rice grains, but some authors report that the genotype Nanyangzhan mainly contains DMA (Pan et al., 2014). Other authors have reported that different rice genotypes grown in greenhouses had As concentrations ranging between 8.3 and $14.0 \mathrm{mg} \mathrm{kg}^{-1}$ in the leaf and between 0.87 and $1.52 \mathrm{mg} \mathrm{kg}^{-1}$ in the grain; however, this study suggests that rice accumulates significant As concentrations under favorable growth conditions (Jomova et al., 2011).

Figure 2. Possible mechanisms of arsenic uptake in rice plants (adapted from Ali et al., 2009).

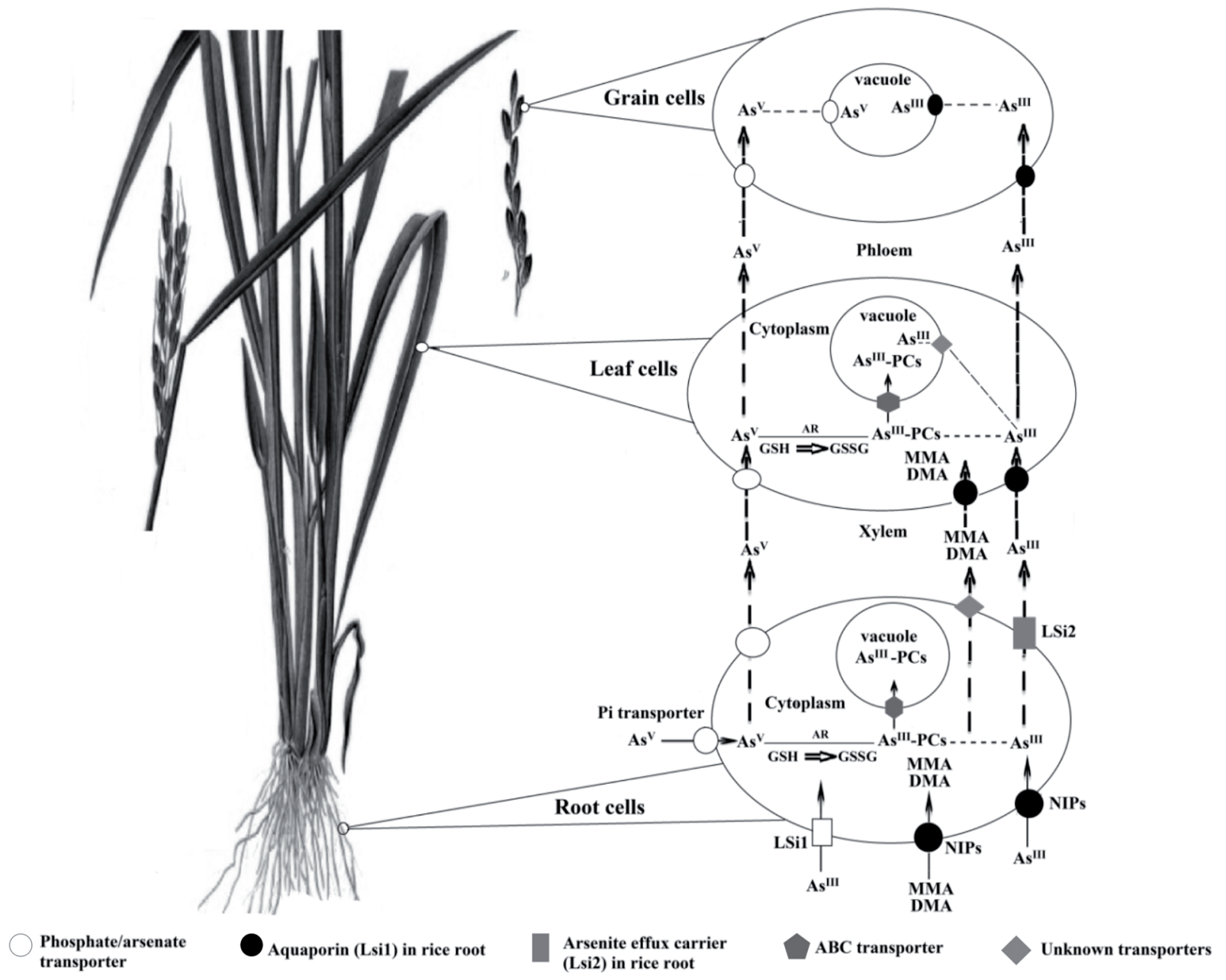

$\mathrm{As}^{\mathrm{V}}$ : Arsenate, $\mathrm{As}^{\mathrm{III}}$ : arsenite, NIP: nodulin-like intrinsic protein, AR: arsenate reductase, GSH: glutathione, GSSG: oxidized glutathione (GSH/GSSG), PCs: phytochelatins, MMA: monomethylarsonate, DMA: dimethylarsonate, LSi1: silicon transporter, LSi2: silicon efflux system. 
When grain size increases, As concentration increases (Zavala and Duxbury, 2008). Findings related to color showed that As concentration is $0.196 \pm 0.111 \mathrm{mg} \mathrm{kg}^{-1}$ in brown rice, $0.127 \pm 0.087 \mathrm{mg} \mathrm{kg}^{-1}$ in white rice, and $0.07 \pm$ $0.05 \mathrm{mg} \mathrm{kg}^{-1}$ for other colors (Zavala and Duxbury, 2008; Sharma et al., 2014). The highest amount of As is in brown rice because its outer layers have a higher content of the metalloid.

Some studies suggest that rice plants lack the ability to methylate As, and its speciation in the grain is mainly attributable to environmental factors such as the methylated As species found in soil (Ma et al., 2014). The main species found in rice from Europe, Bangladesh, India, and the USA are $\mathrm{As}^{\mathrm{III}}, \mathrm{DMA}^{\mathrm{V}}$, and $\mathrm{As}^{\mathrm{V}}$ (Welna et al., 2015).

Arsenic species change in aquatic environments because of the role played by microorganisms (Figure 1), which are particularly active in terms of As methylation under anaerobic conditions of rice cultivation (Lomax et al., 2012). Multiple theories have been proposed to explain the influence of microorganisms on As biotransformation. These reactions (generally oxidation or reduction) are produced by the microorganisms to protect themselves from the toxic effects of this metalloid or generate energy and ensure their growth (Mateos et al., 2010); the biotransformation includes the oxidation of $\mathrm{As}^{\mathrm{III}}$ to $\mathrm{As}^{\mathrm{V}}$ and methylation to methylarsenic forms (Mateos et al., 2010). Among the microorganisms with the proven ability to generate these biotransformations are algae (Cyanidium) and some bacteria (Hydrogenobacter acidophilus). The oxidation mechanism of AsIII by microorganisms includes the chemolithotroph metabolism used as a source of energy (Rahman and Hassler, 2014).

\section{Current legislation for arsenic level in rice grain}

The As concentration permitted by the Codex Alimentarius is $0.3 \mathrm{mg} \mathrm{kg}^{-1}$ for ToAs and $0.2 \mathrm{mg} \mathrm{kg}^{-1}$ for iAs in raw rice (Codex Alimentarius, 2013). Chile has established $0.5 \mathrm{mg} \mathrm{kg}^{-1}$ for cereals and legumes (RSA, 2011) and the same limits permitted by the Codex Alimentarius for rice (Villanueva, 2014).

The accuracy for identifying As compounds depends on the analysis method that is selected (Nearing et al., 2014). Many techniques have been used and innovated to increase both the specificity level and accuracy in results. Most of the studies use the inductively coupled plasmamass spectrometry (ICP-MS) technique coupled to high performance liquid chromatography (HPLC). This is the internationally validated method used to determine ToAs. The two most reported complementary analytical methods for As speciation are X-ray absorption spectroscopy (XAS) and electrospray mass spectrometry (ESI-MS); however, other studies propose different techniques (Table 2).

There are different methods in HPLC that have been used because they have high selectivity and a low detection limit $(<50 \mathrm{pg}$ ), for example, ion exchange (Raber et al., 2012) or ion-pairing reverse phase (Dufailly et al., 2011). HPLC-ICPMS requires procedures to extract As compounds that can be in methanol-water and water extractions. An intermediate heating step with diluted nitric acid to extract iAs species is necessary to increase crop efficiency; efficiency is $90 \%$ when this methodology is used in rice samples. It has been observed in all cases that some As compounds are more easily extracted than others, and this depends on the selected extraction method and sample matrix. A disadvantage of this technique is that the chromatograms provide unstructured information about the separated compounds and the number of patterns is limited (Nearing et al., 2014).

To obtain the necessary detection limits in the XAS method, radiation based on synchrotron is used (giving typical detection limits of approximately 1 to $10 \mathrm{mg} \mathrm{kg}^{-1}$ depending on the experimental conditions). The principles of X-ray fluorescence are generally used in the XAS method for As in environmental samples (Nearing et al., 2014). The X-ray absorption spectra are characterized by a sharp increase in absorption at specific $\mathrm{X}$-ray photon energies giving rise to an absorption edge that characterisizes the element. The problem is that the energy is the same for similar As compounds isolated from the same environments; this is one of the limiting factors of the technique. The most common use of XAS for As speciation is the analysis of $\mathrm{X}$-ray absorption near-edge structure (XANES), which reveals the most probable chemical environment around As by matching the spectral characteristics, including whiteline energy, to the standard compounds. This method has provided good results for the speciation of As compounds in rice (Maher et al., 2013). Studies comparing both methods demonstrate that compounds such as $\mathrm{As}^{\mathrm{III}}-\mathrm{S}$ have not been found by the traditional method, but have been found by XAS; this has been attributed to its oxidation during extraction with nitric acid. Analysis with XAS found As ${ }^{\mathrm{III}}-\mathrm{S}$ compounds in $55.6 \%$ of As in rice endosperm and $12.9 \%$ in the husk (Carey et al., 2012).

The use of ESI-MS to complement HPLC-ICP-MS in determining different As species in rice allowed the tentative identification of DMA, a species not previously found in rice. This method has provided good results in identifying $\mathrm{As}^{\mathrm{III}}-\mathrm{PC}$

Table 2. Principal genetic modifications to obtain seeds with lower ability to accumulate arsenic (Kumar et al., 2015).

\begin{tabular}{|c|c|c|c|c|}
\hline Source & Target & Gene & Consequence & Reference \\
\hline Oryza sativa & O. sativa & As ${ }^{\mathrm{III}} \mathrm{S}$-adenosyl transferase $(\operatorname{ars} M)$ & Decreases As in rice grain & Kumar et al., 2015 \\
\hline O. sativa & O. sativa & Phosphate transporter $(P H T 1 ; 8)$ & Increases phosphate and $\mathrm{As}^{\mathrm{V}}$ absorption and translocation & Wu et al., 2011 \\
\hline O. sativa & O. sativa & Response to phosphate 2 requirement (PHR2) & Increases tolerance to As and greater $\mathrm{As}^{\mathrm{V}}$ efflux capacity & Wu et al., 2011 \\
\hline $\begin{array}{l}\text { Saccharomyces } \\
\text { cerevisiae }\end{array}$ & O. sativa & Arsenate reductase $(A C R 3)$ & $\begin{array}{l}\text { Increases As }{ }^{I I I} \text { efflux } \\
\text { Decreases As accumulation in rice grain }\end{array}$ & Kumar et al., 2015 \\
\hline
\end{tabular}


compounds (Cao et al., 2015). Another methodology used to determine and quantify As is radiochemical neutron activation analysis (RNAA). It uses the irradiation in a nuclear reactor with $1.8 \times 10^{12} \mathrm{n} \mathrm{cm}^{-2} \mathrm{~s}^{-1}$ neutron flux; its As detection limit in the sample is in the $\mathrm{ng} \mathrm{g}^{-1}$ range (Halder et al., 2014). In recent years, analytical techniques have been worked on for As speciation and coupling of a hydride generator coupled to ICP-MS to measure ToAs in rice. Total As is directly measured by this method without any previous treatment of samples. The technique determines all the main As species: $\mathrm{As}^{\mathrm{III}}$, DMA, MMA, and $\mathrm{As}{ }^{\mathrm{V}}$; it eliminates the difference of sensitivity among different organic and inorganic As species when measuring ToAs (Sengupta and Dasgupta, 2009).

While it is true that methods have been developed to allow the detection of ToAs along with its species, reagents introduced in the different techniques to treat samples could transform the species; it is therefore important to develop analytical methods that directly detect the original species in the rice grains (Welna et al., 2015). Nondestructive techniques have been used for this, such as X-ray fluorescence spectrometry (XRF), X-ray absorption near edge structure (XANES), instrumental neutron activation analysis (INNA), and near-infrared spectroscopy (NIRS). No chemical products are used in these instrumental methods and the manipulation of the sample is reduced to washing and/or drying and grinding before analysis (Carey et al., 2012).

\section{Risk of As from rice diet in human health}

No epidemiological studies have been published about the health effects associated with ingesting iAs through rice consumption. Bioavailability should be included in the assessment to evaluate the risk of iAs on human health. There are many possible pathways for human exposure to As, but rice is the second most important in many countries (Rahman et al., 2008). It is important to initiate epidemiological studies about the implication of As on health because it will take decades to understand how elevated rates of As in rice affects human lifetime exposure (Rahman et al., 2014c).

Diet, lipids in particular, has an important effect on As bioaccessibility. Not all the constituents found in the food matrix are bioavailable (Bastías et al., 2013b). Some studies have demonstrated that thiol groups are strongly bound to AsIII in certain protein-rich rice varieties, which can influence its bioaccessibility (Rahman et al., 2014c). Other studies demonstrated a relationship between diet composition and $\mathrm{MMA}^{\mathrm{III}}$ levels found in urine after iAs intake; furthermore, those whose diet was relatively high in vegetables had less probability of developing skin lesions related to As and exhibit differences in the metabolic rate of As consumed (Koch et al., 2013).

After the oral intake of As-contaminated rice, gastrointestinal digestion can release a fraction of the bound matrix and make it accessible. The As fraction that is not absorbed through the small intestine epithelium reaches the colon. Here microorganisms decompose the remainder of the food and more As is released. Some studies have revealed that microorganisms are important contributors in the As speciation changes. Studies exist that explain the role of bacterial biota in the gastrointestinal tract over a wide range of biotransformations that the metalloid undergoes during digestion, including oxidation, reduction, methylation, and thiolation (Alava et al., 2015).

A high amount of As has been found released in the food matrix at the gastric level that can be altered by food composition. Therefore, the difference in diet composition can also differ from the amount of As reaching the colon and the amount of As available for pre-systemic metabolism. The acidic conditions of the stomach increase As bioaccessibility more than in the intestine (Alava et al., 2015). Other studies have observed that $i \mathrm{As}^{\mathrm{V}}$ is released proportionally more easily than $\mathrm{DMA}^{\mathrm{V}}$ from the rice matrix during gastrointestinal digestion. It has been found that iAs species are more likely to bind to the protein matrix of the endosperm cells, especially by the amino acid compounds that contain thiol (Alava et al., 2015).

Different studies show that real exposure to ToAs and iAs through foods depends on the type of food processing, time, temperature, and medium, especially cooking medium. It is absolutely necessary to cook rice because it is not consumed raw (Rahman et al., 2014c). Arsenic concentration has been observed to be lower in dry rice husking than wetting rice with contaminated water before husking it. Another method is to cook one part rice in six parts water; the disadvantage of this method is the higher consumption of energy and water (Rahman et al., 2014c).

\section{Remediation techniques}

Arsenic affects humans and is a public health problem.Better agricultural irrigation practices are therefore proposed to help reduce contamination; one of these techniques is that crops be grown in raised organoponics instead of flooded fields (Rahman et al., 2014c). The code of good agricultural practices for rice cultivation in Chile also proposes using only certified seeds. Selecting the variety to be sown should be based on seeds that are better adapted to the production zone, and the number of seeds per hectare will vary according to the type used, soil preparation conditions, sowing system, and water management.

Studies of soil and water remediation continue using phytoremediation and mycoremediation. In the case of As, the use of a hyperaccumulator fern, Pteris vittata L., has been proposed (Rascio and Navari-Izzo, 2011). The limitation of this method is that the plant absorbs As without using it and can be transferred back to the food chain (Singh et al., 2015). Fungi have the ability to counteract As toxicity by transforming organic forms with reduced toxicity (Tsai et al., 2009). The behavior of Glomus geosporum (Gg), G. mosseae $(\mathrm{Gm})$, and G. versiforme $(\mathrm{Gv})$ was studied to minimize As absorption by the rice plant; it was found that species, taken separately or mixed, can be used because the amount of As decreases in all cases (Chan et al., 2013). Redox changes mediated by rhizosphere microorganisms 
can influence As absorption in the rice plant (Jia et al., 2014). However, the participation of microbes in As oxidation and reduction during the interaction with the root has not been studied in detail.

Using seeds with modified As absorption genes is another alternative. By restricting the influx of As, its toxicity is avoided (Rahman et al., 2014c). The main variations have been performed on phosphate transporter genes (Wu et al., 2011) and $\operatorname{ars} M$ (As ${ }^{\mathrm{III}}$ S-adenosyltransferase), which decrease As in rice. The gene PHT 1;8 and PHR2 increase root tolerance to As in the rice plant and also increase the efflux ability of $\mathrm{As}^{\mathrm{V}}$. The main genetic modifications to obtain seeds with lower As accumulation ability are shown in Table 2.

Soil fertilization with $\mathrm{Si}$ is advantageous because it decreases ToAs concentration in the straw and grain, $78 \%$ and $16 \%$, respectively, although adding $\mathrm{Si}$ increases As concentration in the soil solution. Silicon decreases iAs concentration in the grain by $59 \%$ (Tripathi et al., 2013). On the other hand, $\mathrm{Fe}$ is an important factor in regulating bioavailability and As absorption in rice plants because it creates a zone around the roots in which it is oxidized and precipitated to form a sheath, and $\mathrm{As}^{\mathrm{V}}$ has a high binding affinity with the precipitated $\mathrm{Fe}$ hydroxides that act as an As filter to reduce its absorption by the rice plant (Garnier et al., 2010). Sulfur improves the formation of Fe coating in the rhizosphere and reduces As accumulation, but adding nitrate decreases the formation of $\mathrm{Fe}$ coating on the root surface of rice; however, $\mathrm{S}$ reduces As absorption by the rice plant (Hu et al., 2015).

\section{CONCLUSIONS}

The root of the rice plant is able to absorb and accumulate large amounts of As, but only small amounts are translocated to the grain and tillers. Arsenic concentrations in rice tissues decrease from the root to the grain. Information about As translocation in rice is sparse and research is directed toward studying the molecular mechanism of absorption and accumulation in the grain because it has not yet been explained. Some rice varieties have been developed that are resistant to high soil As concentrations and are not able to translocate the metalloid toward the root.

Many studies suggest that not all ingested iAs accumulated in the gastrointestinal tract is absorbed into the bloodstream and produces toxicity. It is therefore recommended that As species found in different types of diets be studied, as well as the influence of bacterial biota of the gastrointestinal tract on the bioavailability of different As species and their release after intake. Arsenic bioavailability in imported or domestic Chilean rice should be evaluated, thus contributing to studies estimating its exposure and providing a more precise risk estimate.

\section{ACKNOWLEDGEMENTS}

The authors thank the Research Department and the Control, Toxicology, and Food Safety Research Group of the Universidad del Bío-Bío, Chile, for the funds provided to conduct the present study.

\section{REFERENCES}

Abedin, M.J., M.S. Cresser, A.A. Meharg, J. Feldmann, and J. Cotter-Howells. 2002. Arsenic accumulation and metabolism in rice (Oryza sativa L.) Environmental Science and Technology 36:962-968. doi:10.1021/es0101678.

Alava, P., G.D. Laing, F. Tack, T. De Ryck, and T.V. de Wiele. 2015. Westernized diets lower arsenic gastrointestinal bioaccessibility but increase microbial arsenic speciation changes in the colon. Chemosphere 119:757-762. doi:10.1016/j. chemosphere.2014.08.010.

Ali, W., S.V. Isayenkov, F.J. Zhao, and F.J. Maathuis. 2009. Arsenite transport in plants. Cellular and Molecular Life Sciences 66:2329-2339. doi:10.1007/s00018-009-0021-7.

Bastías, J.M.,C. Fuentealba, and O. Muñoz. 2013a. Bioaccessibility and bioavailability of bioactive compounds in food and plant determination. p. 45-56. In Céspedes, L.C., D.A. Sampietro, D.S Seigler, M. Rai (eds.) Natural Antioxidants and Biocides from Wild Medicinal Plants. CABI, London, UK.

Bastías, J.M., P. Jambon, O. Muñoz, N. Manquián, P. Bahamonde, and M. Neira. 2013b. Honey as a bioindicator of arsenic contamination due to volcanic and mining activities in Chile. Chilean Journal of Agricultural Research 73:147-153. doi:10.4067/S0718-58392013000200010.

Bundschuh, J., C.W. Liu, J.S. Jean, M.A. Armienta, M.V. MorenoLópez, and L. Cornejo. 2012. Arsenic in the human food chain: the Latin American perspective. Science of the total Environment 429:92-106. doi:10.1016/j.scitotenv.2011.09.069.

Cao, Z.Y., L.H. Sun, R.X. Mou, R. Zhou, Z.W. Zhu, and M.X. Chen. 2015. A novel method for the simultaneous analysis of seven biothiols inrice (Oryza sativa L.) using hydrophilic interaction chromatography coupled with electrospray tandem mass spectrometry. Journal of Chromatography B 976-977:1926. doi:/10.1016/j.jchromb.2014.11.007.

Carey, A.M., E. Lombi, E. Donner, M.D. de Jonge, T. Punshon, B.P. Jackson, et al. 2012. A review of recent developments in the speciation and location of arsenic and selenium in rice grain. Analytical and Bioanalytical Chemistry 402:3275-3286. doi:10.1007/s00216-011-5579-x.

Chan, W.F., H.Li, F.Y.Wu, S.C. Wu, and M.H. Wong. 2013. Arsenic uptake in upland rice inoculated with a combination or single arbuscular mycorrhizal fungi. Journal of Hazardous Materials 262:1116-1122. doi: 10.1016/j.jhazmat.2012.08.020 .

Codex Alimentarius. 2013. Programa conjunto FAO/OMS sobre normas alimentarias. Comité del Codex sobre contaminantes de los alimentos. CX/CF 13/7/13, Febrero 2013.

Deng, D., S.Ch. Wu, F.Y. Wu, and H. Deng. 2010. Effects of root anatomy and $\mathrm{Fe}$ plaque on arsenic uptake by rice seedlings grown in solution culture. Environmental Pollution 158:2589-2595. doi:10.1016/j.envpol.2010.05.015.

Dopp, E., U. von Recklinghausen, R. Diaz-Bone, A.V. Hirner, and A.W. Rettenmeier. 2010. Cellular uptake, subcellular distribution and toxicity of arsenic compounds inmethylating and nonmethylating cells. Environmental Research 110:435-442. doi:10.1016/j.envres.2009.08.012. 
Dufailly, V., M. Nicolas, J. Richoz-Payot, and E. Poitevin. 2011. Validation of a method for arsenic speciation in food by ion chromatography-inductively coupled plasma/mass spectrometry after ultrasonic-assisted enzymatic extraction. Journal of AOAC International 94:947-958.

Gan, Y., Y. Wang, Y. Duan Y. Deng, X. Guo, and X. Ding. 2014. Hydrogeochemistry and arsenic contamination of groundwater in the Jianghan Plain, central China. Journal of Geochemical Exploration 138:81-93. doi:10.1016/j.gexplo.2013.12.013.

Garnier, J.M., F. Travassac, V. Lenoble, J. Rose, Y. Zheng, M.S. Hossain, et al. 2010. Temporal variations in arsenic uptake by rice plants in Bangladesh: The role of iron plaque in paddy fields irrigated with groundwater. Science of the Total Environment 408:4185-4193. doi:10.1016/j.scitotenv.2010.05.019.

Halder, D., A. Biswas, Z. Šlejkovec, D. Chatterjee, J. Nriagu, G. Jacks, et al. 2014. Arsenic species in raw and cooked rice: Implications for human health in rural Bengal. Science of Total Environment 497-498:200-208. doi:10.1016/j. scitotenv.2014.07.075.

Hu, P., Y. Ouyang, L. Wu, L. Shen, Y. Luo, and P. Christie. 2015. Effects of water management on arsenic and cadmium speciation and accumulation in an upland rice cultivar. Journal of Environmental Sciences 27:225-231. doi:10.1016/j. jes.2014.05.048.

IARC. 2012. Arsenic and arsenic compounds. p. 41-94. In IARC Monographs on the Evaluation of Carcinogenic Risks to Humans. Arsenic, metals, fibres, and dusts. Volume 100c A review of human carcinogens. International Agency for Research on Cancer (IARC), Lyon, France.

Jia, Y., H. Huang, Z. Chen, and Y.G. Zhu. 2014. Arsenic uptake by rice is influenced by microbemediated arsenic redox changes in the rhizosphere. Environmental Science and Technology 48:1001-1007. doi:10.1021/es403877s.

Jiang, W., Q. Hou, Z. Yang, C. Zhong, G. Zheng, Z. Yang, et al. 2014. Evaluation of potential effects of soil available phosphorus on soil arsenic availability and paddy rice inorganic arsenic content. Environmental Pollution 188:159-165. doi:10.1016/j. envpol.2014.02.014.

Jomova, K., Z. Jenisova, M. Feszterova, S. Baros, J. Liska, D Hudecova, et al. 2011. Arsenic: toxicity, oxidative stress and human disease. Journal of Applied Toxicology 31:95-107. doi: $10.1002 /$ jat.1649.

Koch, I., J. Dee, K. House, J. Sui, J. Zhang, A. McKnight-Whitford, et al. 2013. Bioaccessibility and speciation of arsenic in country foods from contaminated sites in Canada. Science of the Total Environment 449:1-8. doi:10.1016/j.scitotenv.2013.01.047.

Kumar, S., R.S. Dubey, R.D. Tripathi, D. Chakrabarty, and P.K Trivedi. 2015. Omics and biotechnology of arsenic stress and detoxification in plants: Current updates and prospective. Review. Environment International 74:221-230. doi:10.1016/j. envint.2014.10.019.

Lomax, C., W.J. Liu, L.Y. Wu, K. Xue, J. Xiong, and J.Z. Zhou. 2012. Methylated arsenic species in plants originate from soil microorganisms. New Phytologist 193:665-672. doi:10.1111/ j.1469-8137.2011.03956.x.

Ma, R., J. Shen, J. Wu, Z. Tang, Q. Shen, and F.J. Zhao. 2014. Impact of agronomic practices on arsenic accumulation and speciation in rice grain. Environmental Pollution 194:217-223. doi:10.1016/j.envpol.2014.08.004.

Maher, W., S. Foster, F. Krikowa, E. Donner, and E. Lombi. 2013. Measurement of inorganic arsenic species in rice after nitric acid extraction by HPLC-ICPMS: verification using XANES. Environmental Science and Technology 47:5821-5827. doi:23621828.

Mateos, L.M., E. Ordóñez, M. Letek, and J.A. Gil. 2010. Corynebacterium glutamicum as a model bacterium for the bioremediation of arsenic. International Microbiology 9:207-215.
Meharg, A.A., and L. Jardine. 2003. Arsenite transport into paddy rice (Oryza sativa) roots. New Phytologist 157:39-44. doi:10.1046/j.1469-8137.2003.00655.x.

Meharg, A.A., E. Lombi, P.N. Williams, K.G. Scheckel, J. Feldmann, and A. Raab. 2008. Speciation and localization of arsenic in white and brown rice grains. Environmental Science and Technology 42:1051-1057. doi:10.1021/es702212p.

Meharg, A.A., and F.J. Zhao. 2012. Arsenic and rice. Springer, New York, USA.

Michael, H.A. 2013. An arsenic forecast for China. Science 341:852-853. doi:10.1126/science.1242212.

Mosa, K.A., K. Kumar, S. Chhikara, J. Mcdermott, Z. Liu, C. Musante, et al. 2012. Members of rice plasma membrane intrinsic proteins subfamily are involved in arsenite permeability and tolerance in plants. Transgenic Research 21:1265-1277. doi:10.1007/s11248-012-9600-8.

Nearing, M.M., I. Koch, and K.J. Reimer. 2014. Complementary arsenic speciation methods: A review. Spectrochimica Acta Part B 99:150-162. doi:10.1016/j.sab.2014.07.001.

ODEPA. 2014. La producción mundial de arroz 20142015. Oficina de Estudios y Políticas Agrarias (ODEPA), Ministerio de Agricultura, Santiago, Chile. Available at http://www.produccionmundialarroz.com/?gclid=CML_i4kh8ICFW8V7AodIUUAlA (accessed October 2014).

Pan, W., Ch. Wu, Sh. Xue, and W. Hartley. 2014. Arsenic dynamics in the rhizosphere and its sequestration on rice roots as a selected by root oxidation. Journal of Environmental Sciences 26:892899. doi:10.1016/S1001-0742(13)60483-0.

Raber, G., N. Stock, P. Hanel, M. Murko, J. Navratilova, and K.A. Francesconi. 2012. An improved HPLC-ICPMS method for determining inorganic arsenic in food: application to rice, wheat and tuna fish. Food Chemistry 134:524-532. doi:org/10.1016/j. foodchem.2012.02.113.

Rahman, M.A., H. Hasegawa, M.M. Rahman, M.A.M. Miah, and A. Tasmin. 2008. Arsenic accumulation in rice (Oryza sativa L.): Human exposure through food chain. Ecotoxicology and Environmental Safety 69:317-324. doi:10.1016/j. ecoenv.2007.01.005.

Rahman, M.A., and Ch. Hassler. 2014. Is arsenic biotransformation a detoxification mechanism for microorganisms? Aquatic Toxicology 146:212-219. doi:10.1016/j.aquatox.2013.11.009.

Rahman, M.A., K. Kadohashi, T. Maki, and H. Hasegawa. 2011. Transport of DMAA and MMAA into rice (Oryza sativa L.) roots. Environmental and Experimental Botany 72:41-46. doi:10.1016/j.envexpbot.2010.02.004.

Rahman, S., K.H. Kim, S.K. Saha, A.M. Swaraz, and D.K. Paul. 2014a. Review of remediation techniques for arsenic (As) contamination: A novel approach utilizing bio-organisms. Journal of Environmental Management 134:175-185. doi:10.1016/j. jenvman.2013.12.027.

Rahman, M.M., D. Mondal, B. Das, M.K. Sengupta, S. Ahamed, M.A. Hossain, et al. 2014b. Status of groundwater arsenic contamination in all 17 blocks of Nadia district in the state of West Bengal, India: A 23-year study report. Journal of Hydrology 518:363372. doi:10.1016/j.jhydrol.2013.10.037

Rahman, M.A., M. Rahman, and R. Naidu. 2014c. Arsenic in rice: Sources and human health risk. p. 365-375. In Watson, R.R., V.R. Preedy, and S. Zibadi (eds.) Wheat and rice in disease prevention and health benefits, risks and mechanisms of whole grains in health promotion. Elsevier, Oxford, UK.

Rai, A., P. Tripathi, S. Dwivedi, S. Dubey, M. Shri, S. Kumar, et al. 2011. Arsenic tolerances in rice (Oryza sativa) have a predominant role in transcriptional regulation of a set of genes including sulphur assimilation pathway and antioxidant system. Chemosphere 82:986-995. doi:10.1016/j. chemosphere.2010.10.070. 
Rascio, N., and F. Navari-Izzo. 2011. Heavy metal hyperaccumulating plants: How and why do they do it? And what makes them so interesting? Review. Plant Science 180:169-181. doi:10.1016/j.plantsci.2010.08.016.

RSA. 2011. Decreto 977/96 (actualizado 2013). Reglamento Sanitario de los Alimentos (RSA), Ministerio de Salud, Gobierno de Chile, Santiago, Chile.

Sengupta, M.K., and P.K. Dasgupta. 2009. An automated hydride generation interface to ICP-MS for measuring total arsenic in environmental samples. Analytical Chemistry 81:9737-9743. doi:10.1039/b109754g.

Sharma, A.K., J.Ch. Tjell, J.J. Sloth, and P.E. Holm. 2014. Review of arsenic contamination, exposure through water and food and low cost mitigation options for rural areas. Applied Geochemistry 41:11-33. doi:10.1016/j.apgeochem.2013.11.012.

Singh, S., P. Parihar, V.P. Singh, and S.M. Prasad. 2015. Arsenic contamination, consequences and remediation techniques: A review. Ecotoxicology and Environmental Safety 112:247-270. doi:10.1016/j.ecoenv.2014.10.009.

Su, Y.H., S.P. McGrath, and F.J. Zhao. 2010. Rice is more efficient in arsenite uptake and translocation than wheat and barley. Plant and Soil 328:27-34. doi:10.1007/s11104-009-0074-2.

Tong, J., H. Guo, and Ch. Wei. 2014. Arsenic contamination of the soil-wheat system irrigated with high arsenic groundwater in the Hetao Basin, Inner Mongolia, China. Science of the Total Environment 496:479-487. doi:10.1016/j.scitotenv.2014.07.073.

Tripathi, P., R.D. Tripathi, R.P. Singh, S. Dwivedi, D. Goutam, M. Shri, et al. 2013. Silicon mediates arsenic tolerance in rice (Oryza sativa L.) through lowering of arsenic uptake and improved antioxidant defence system. Ecological Engineering 52:96-103. doi:10.1016/j.ecoleng.2012.12.057.
Tsai, S.L., S. Singh, and W. Chen. 2009. Arsenic metabolism by microbes in nature and the impact on arsenic remediation. Current Opinion in Chemical Biology 20:659-667. doi:10.1016/j. copbio.2009.09.013.

Villanueva, M. 2014. El Codex Alimentarius establece nuevos niveles de plomo para la comida infantil y de arsénico para el arroz. Available at http://chilealimentosinocuos.blogspot. com/2014/08/se-fijan-nuevos-niveles-de-metales.html (accessed November 2014).

Welna, M., A. Szymczycha-Madeja, and P. Pohl. 2015. Comparison of strategies for sample preparation prior to spectrometric measurements for determination and speciation of arsenic in rice. Trends in Analytical Chemistry 65:122-136.

Wu, Z., H. Ren, S.P. McGrath, P. Wu, and F.J. Zhao. 2011 Investigating the contribution of the phosphate transport pathway to arsenic accumulation in rice. Plant Physiology 157:498-508 doi:10.1104/pp.111.178921

Yu, L.J., Y.F. Luo, B. Liao, L.J. Xie, L. Chen, S. Xiao, et al. 2010. Comparative transcriptome analysis of transporters, phytohormone and lipid metabolism pathways in response to arsenic stress in rice (Oryza sativa). New Phytologist 195:97112. doi:10.1111/j.1469-8137.2012.04154.x.

Zavala, Y.J., and J.M. Duxbury. 2008. Arsenic in rice. 1. Estimating normal levels of total arsenic in rice grain. Environmental Science and Technology 42:3856-3860. doi:10.1021/es702747y.

Zhao, F.J., S.P. McGrath, and A.A. Meharg. 2010. Arsenic as a foodchain contaminant: mechanisms of plant uptake and metabolism and mitigation strategies. Annual Review of Plant Biology 61:535-559. doi:10.1146/annurev-arplant-042809-112152. 